\title{
Upaya Peningkatan Hasil Belajar Soal Cerita Melalui Pendekatan Contextual Teaching and Learning (CTL) Pada Siswa Kelas III Sekolah Dasar Negeri 07 Batang Anai
}

\section{Jusmaini}

\begin{abstract}
Abstrak
Berdasarkan pengamatan peneliti di SDN 17 Nan Sabaris dan hasil wawancara terhadap siswa dan guru kelas III SDN 17 Nan Sabaris, siswa kurang memahami soal cerita, serta pembelajaran dilaksanakan oleh guru masih secara konvensional. Hal ini mengakibatkan nilai siswa rendah, yakni pencapaian nilai rata-rata siswa secara klasikal adalah 5,4. Untuk itu penulis melalui penelitian ini mencoba meningkatkan hasil belajar siswa dalam menyelesaikan soal cerita melalui pendekatan CTL. Tujuan dari penelitian ini adalah untuk mendeskripsikan perencanaan, bentuk pelaksanaan dan hasil pembelajaran soal cerita melalui pendekatan CTL. Pembelajaran dengan menggunakan pendekatan CTL mempunyai 7 langkah, yaitu konstuktivisme, menemukan, bertanya, masyarakat belajar, pemodelan, refleksi, dan penilaian yang sebenarnya. Langkah pendekatan CTL tersebut dikombinasikan dengan langkah-langkah menyelesaikan soal cerita. Jenis penelitian ini adalah penelitian tindakan kelas (class action research), penelitian ini menggunakan pendekatan kualitatif dan kuantitatif. Sedangkan siswa yang diambil sebagai subjek penelitian adalah seluruh siswa kelas III SDN 17 Nan Sabaris. Data penelitian ini diperoleh dengan menggunakan tes, observasi, wawancara, dan catatan lapangan.Hasil penelitian dari setiap siklus yang dilaksanakan dalam peneitian ini terlihat peningkatan hasil belajar siswa dari tes awal dengan rata-rata 5,6 dan pada tes akhir tindakan siklus I rata-rata hasil belajar siswa 6.8, sedangkan pada tes akhir tindakan siklus II rata-rata nilai siswa yakni 8,46. Hasil pengamatanpun terlihat peningkatan keaktifan siswa dalam proses pembelajaran. Penulis mengambil simpulan pada penelitian ini bahwa dengan menggunakan pendekatan CTL dapat meningkatkan hasil belajar siswa.
\end{abstract}

Keyword: Soal Cerita, Contextual Teaching And Learning

Copyright (C) 2016 IICET (Padang - Indonesia) - All Rights Reserved Indonesian Institute for Counseling, Education and Theraphy (IICET)

\section{PENDAHULUAN}

Soal cerita merupakan salah satu cara memahami konsep dalam pembelajaran matematika di Sekolah Dasar (SD), penyajianya dalam bentuk kalimat-kalimat sederhana. Soal cerita membutuhkan penelaahan maksud dari soal tersebut. Penelaahan dengan pemahaman yang baik dapat mengembangkan tiga aspek yaitu aspek kognitif (pengetahuan), aspek afektif (sikap) dan aspek psikomotor (keterampilan), yang dituntut dalam Kurikulum Tingkat Satuan Pendidikan (KTSP 2006). Ketiga aspek tersebut sangat berpengaruh terhadap perkembangan berfikir produktif siswa yaitu berfikir terarah untuk menyelesaikan masalah (Hamdani 2008:1) khususnya dalam menyelesaikan soal cerita di sekolah dasar.

Soal cerita merupakan soal ungkapan kalimat-kalimat dalam bentuk cerita dan masalahnya dapat dikaitkan dengan pelajaran matematika. Menurut Budhi (2006:22) "Soal cerita merupakan soal yang berbentuk cerita tentang sesuatu hal yang berkaitan dengan kehidupan sehari-hariMenurut Sumardjati (2005:23) soal cerita merupakan soal matematika yang dinyatakan dalam bentuk cerita. Sedangkan menurut Budhi (2006:22) soal cerita adalah soal yang berbentuk cerita tentang sesuatu hal yang berkaitan dengan kehidupan sehari-hari.

Menurut Hamdani (2008:5) dalam menyelesaikan soal cerita terlebih dahulu siswa harus memahami maksud dari soal tersebut. Kemudian baru memisahkan dan mengungkapkan apa yang diketahui, ditanya, dan penyelesaian soal cerita yaitu mentransformasikan bahasa verbal menjadi kalimat matematika.

Agar soal cerita dapat diselesaikan dengan baik diperlukan suatu pendekatan pembelajaran yang dapat meningkatkan hasil belajar siswa. Menurut Subana dan Sunarti (2000:20) "Pendekatan pembelajaran mempunyai pengaruh besar terhadap hasil yang diharapkan". Salah satu pendekatan pembelajaran yang dapat digunakan dalam pembelajaran soal cerita adalah pendekatan Contextual Teaching and Learning (CTL). 
Menurut Nurhadi (2003:11) pendekatan CTL bertujuan mengintegrasikan ide matematika ke dalam konteks kehidupan nyata dengan harapan siswa dapat memahami apa yang dipelajarinya dengan baik dan mudah.

Menurut Kunandar (2008:293) "Pendekatan CTL adalah konsep belajar yang beranggapan bahwa siswa akan belajar lebih baik jika lingkungan diciptakan secara alamiah". Artinya belajar akan lebih bermakna jika siswa bekerja dan mengalami sendiri apa yang dipelajarinya, bukan sekedar mengetahuinya. Sedangkan menurut Wina (2008:225) pendekatan CTL adalah suatu pendekatan pembelajaran yang menekankan kepada proses keterlibatan siswa secara penuh untuk dapat menemukan materi yang dipelajari. Materi tersebut kemudian dihubungkan dengan situasi kehidupan nyata sehingga mendorong siswa untuk dapat menerapkannya dalam kehidupan sehari-hari.

Menurut Nurhadi (2003:5) pendekatan CTL juga mempunyai manfaat, yaitu siswa dapat memecahkan masalah yang dihadapi dalam kehidupannya sebagai anggota keluarga dan masyarakat. Karena materi yang diberikan kepada siswa adalah masalah-masalah yang ada di lingkungannya .

Dari observasi dan wawancara peneliti dengan kepala sekolah, masih banyak siswa yang kurang mengerti dalam menyelesaikan soal cerita tentang keliling persegi dan persegi panjang. Siswa kurang memahami maksud dari soal cerita. Sehingga tidak bisa membedakan mana yang diketahui, ditanya, dan penyelesaian dari soal cerita tersebut. Hal ini dapat dilihat dari hasil belajar soal cerita siswa yang rendah, yaitu dengan rata-rata 5,4. Sedangkan mata pelajaran yang lain rata-ratanya lebih tinggi dibandingkan matematika, seperti PKn rata-ratanya 7,6, Bahasa Indonesia rata-ratanya 7,4, IPA rata-ratanya 6,8 dan IPS rata-ratanya 7,1 .

Berdasarkan hasil observasi faktor yang menyebabkan rendahnya nilai siswa adalah: pertama, guru hanya memberikan soal-soal yang ada di dalam buku paket tanpa mengaitkannya dengan kehidupan seharihari siswa. Kedua, guru masih menggunakan metode konvensional, yaitu metode ceramah dan bersifat monoton dalam pembelajaran.

Menurut Manan (dalam Megawati, 2004:10) pembelajaran matematika secara konvensional siswa diposisikan sebagai orang yang tidak tahu apa-apa. Siswa hanya menunggu dan menyerap apa yang diberikan guru, akibatnya siswa pasif dan guru menjadi aktif. Sedangkan guru hanya mentransfer pengetahuan kepada siswa tanpa memperhitungkan apakah ilmu yang ditransfer itu dapat diterima oleh siswa atau tidak, sehingga tujuan pembelajaran tidak tercapai dengan baik.

\section{METODOLOGI PENELITIAN}

Penelitian ini dilakukan di SDN 07 Batang Anai. Lokasi ini dipilih sebagai tempat penelitian dengan pertimbangkan sebagai berikut. Pertama, guru cendrung menggunakan model pembelajaran konvensional, tanpa menekankan pemahaman konsep matematika. Kedua, belum pernah dilaksanakannya pembelajaran yang menggunakan pendekatan CTL dalam menyelesaikan soal cerita pada SDN 07 Batang Anai. Ketiga, sekolah ini tempat peneliti bertugas.

Penelitian tindakan kelas ini dilakukan pada siswa kelas III semester II SDN 07 Batang Anai. Jumlah siswanya yaitu 25 orang, 10 orang laki-laki dan 15 orang perempuan. Peneliti mengambil subjek penelitian di kelas III karena pembelajaran soal cerita tentang keliling persegi dan persegi panjang merupakan permasalahan yang terdapat pada siswa kelas III SDN 07 Batang Anai.

Penelitian ini dilaksanakan pada semester dua tahun ajaran 2015/2016 di kelas III SDN 07 Batang Anai. Lama penelitian adalah 3 bulan, mulai bulan Januari s/d Maret 2016. Pendekatan yang digunakan dalam penelitian ini adalah pendekatan kualititaf. Pendekatan ini berkenaan dengan perbaikan atau peningkatan proses pembelajaran pada suatu kelas.

Jenis penelitian yang dilakukan merupakan penelitian tindakan kelas (action research) dibidang pendidikan dan pembelajaran matematika. Menurut Wardhani (2007:1.4) penelitian tindakan kelas adalah penelitian yang dilakukan oleh guru di dalam kelasnya sendiri dengan tujuan untuk memperbaiki kinerjanya sebagai guru, sehingga hasil belajar siswa meningkat. Sedangkan menurut Kunandar (2008:44) penelitian tindakan kelas adalah penelitian yang dilakukan oleh guru yang sekaligus sebagai peneliti di kelasnya atau bersama-sama dengan orang lain (kolaborasi). Penelitian dilakukan dengan jalan merancanag, melaksanakan, dan merefleksikan tindakan secara kolaboratif dan partisipatif yang bertujuan unutk memperbaiki proses pembelajaran di kelas melalui suatu tindakan dalam suatu siklus.

Menurut Wardhani (2007:2.3) proses penelitian tindakan kelas dapat dilaksanakan melalui proses pengkajian berdaur ulang atau siklus yang terdiri dari empat tahap yaitu mengembangkan perencanaan, melakukan tindakan sesuai rencana, melakukan observasi terhadap tindakan, dan melakukan refleksi yaitu perenungan terhadap perencanaan, kegiatan tindakan, dan kesuksesan hasil yang diperoleh. Sesuai dengan prinsip umum penelitian tindakan dilaksanakan secara bertahap. Setiap tahapan dan siklusnya selalu searah partisipatoris dan kolaboratif antara peneliti dan kepala sekolah. 
Penelitian tindakan kelas yang dilaksanakan menggunakan model siklus yang dikembangkan oleh Kemmis dan Mc Taggart (dalam Ritawati, 2008:9). Model siklus ini mempunyai empat komponen utama yaitu perencanaan, tindakan, pengamatan, dan refleksi. Penelitian ini dilaksanakan dua siklus. Dalam satu siklus terdapat dua kali pertemuan. Setiap akhir siklus dilakukan tes akhir tindakan. Pada setiap pertemuan dilakukan pengamatan terhadap aktivitas siswa dan guru selama proses pembelajaran yaitu selama 2x35 menit. Setelah akhir setiap siklus dilakukan tes hasil belajar. Alur penelitian tindakan ini dapat dlihat pada bagan berikut:

Data penelitian berupa hasil pengamatan, wawancara dari pembelajaran menyelesaikan soal cerita dengan pendekatan CTL pada siswa kelas III SDN 07 Batang Anai. Data tersebut berkaitan dengan perencanaan, pelaksanaan dan hasil pembelajaran yang berupa informasi sebagai berikut:

a. Pelaksanaan pembelajaran yang berhubungan dengan perilaku guru dan siswa yang meliputi interaksi belajar mengajar antara guru dan siswa, siswa dan siswa, siswa dan guru dalam pembelajaran menyelesaikan soal cerita.

b. Evaluasi pembelajaran menyelesaikan soal cerita yang berupa evaluasi proses maupun evaluasi hasil.

c. Hasil tes siswa baik sebelum maupun sesudah pelaksanaan tindakan pembelajaran menyelesaikan soal cerita.

Sumber data penelitian adalah proses pembelajaran tentang pembelajaran menyelesaikan soal cerita dengan pendekatan CTL yang meliputi perencanaan pembelajaran dan pelaksanaan pembelajaran serta hasil pembelajaran. Data diperoleh dari subjek terteliti yakni guru dan siswa kelas III SDN 07 Batang Anai. Data penelitian dikumpulkan dengan menggunakan pencataan lapangan, observasi, wawancara dan hasil tes. Berikut uraiannya:

a. Pencatatan lapangan

Berupa paparan tentang data pengamatan terhadap praktisi sewaktu pembelajaran menyelesaikan soal cerita dengan pendekatan CTL tentang keliling persegi dan persegi panjang. Unsur-unsur yang diamati dalam pelaksanaan tertera pada lembaran observasi.

b. Observasi

Dilakukan untuk mengamati latar kelas tempat berlangsungnya pembelajaran menyelesaikan soal cerita melalui pendekatan CTL dengan berpedoman pada lembaran observasi peneliti mengamati apa yang terjadi selama proses belajar mengajar. Unsur-unsur yang menjadi sasaran pengamatan dalam proses pembelajaran ditandai dengan memberikan ceklis di kolom yang ada pada lembaran observasi.

c. Wawancara

Digunakan untuk memperkuat data observasi yang terjadi di kelas baik unsur guru maupun siswa. Wawancara dilakukan pada siswa untuk memperoleh data yang berkaitan dengan menyelesaikan soal cerita. Hal ini untuk memperjelas perilaku belajar dan proses berpikir siswa selama proses belajar mengajar berlangsung.

d. Tes

Digunakan untuk memperkuat data observasi yang terjadi dalam kelas terutama pada butir hasil pembelajaran dari unsur siswa.

Data yang diperoleh dalam penelitian dianalisis dengan menggunakan analisis data kualitatif dan kuantitatif. Menurut Subagyo (2006:106) analisis data kualitatif dilakukan terhadap data yang berupa informasi dan uraian yang berupa penjelasan-penjelasan. Sedangkan analisis data kuantitatif dilakukan terhadap data yang berupa angka-angka atau hasil belajar siswa. Data tersebut direduksi berdasarkan masalah yang diteliti, diikuti penyajian data dan terakhir penyimpulan atau verifikasi. Tahap analisis yang demikian dilakukan berulang-ulang sampai data selesai dikumpulkan.

\section{HASIL DAN PEMBAHASAN PENELITIAN \\ Hasil Penelitian \\ Siklus I}

Aktivitas guru dalam kegiatan pembelajaran pada pertemuan I secara umum berlangsung sesuai dengan rencana yang telah disusun sebelumnya. Peneliti selaku guru telah berhasil memberikan bimbingan kepada siswa untuk mengkonstruksi sendiri pemahamannya tentang materi yang diajarkan. Kenyataan ini didukung oleh hasil pengamatan aktivitas guru yang dilakukan kepala sekolah selaku pengamat dengan menggunakan lembaran pengamatan.

Jumlah skor yang peneliti peroleh dalam melaksanakan pembelajaran dengan menggunakan pendekatan CTL adalah 26 dan skor maksimal 36. Dengan demikian persentase rata-ratanya adalah 72,2\%. Hal ini menunjukkan bahwa taraf keberhasilan guru dalam meenggunakan pendekatan CTL selama proses pembelajaran berdasarkan hasil pengamat adalah dalam kategori cukup. 
Dalam kegiatan pembelajaran pertemuan I, siswa telah terlihat cukup serius dan bersemangat mengikuti proses pembelajaran. Kondisi tersebut juga didukung oleh hasil pengamatan aktivitas siswa yang dilakukan selaku pengamat dengan berpedoman kepada lembaran observasi siswa. Dari hasil pengamatan tersebut, masih ada langkah-langkah yang tidak terlaksana dengan baik sehingga pembelajaran pada pertemuan I belum sempurna.

Hasil observasi yang dilakukan pengamat terhadap aktivitas siswa dalam kegiatan pembelajaran yaitu dengan memberikan tanda cek. Kriteria keberhasilan aktivitas siswa juga mengaju pada kriteria keberhasilan aktivitas guru. Dalam menggunakan pendekatan CTL masih banyak karakteristik yang keempat deskriptornya belum terlaksana dengan baik. Hanya ada satu deskriptor yang mendapat kualifikasi sangat baik, yaitu dalam menerima LKS yang dibagikan guru. Sedangkan deskriptor yang lainnya mendapat kualifikasi baik dan cukup.

Jumlah skor yang diperoleh siswa dalam melaksanakan pembelajaran dengan menggunakan pendekatan CTL adalah 25 dan skor maksimal 36. Dengan demikian persentase rata-ratanya adalah 69,4\%. Hal ini menunjukkan bahwa taraf keberhasilan siswa dalam menggunakan pendekatan CTL berada dalam kategori kurang. Hasil pengamatan terhadap aktivitas guru dan siswa juga menggunakan lembaran catatan lapangan. Catatan lapangan ini dibuat untuk mencatat hal-hal penting selama kegiatan pembelajaran yang tidak termuat dalam pedoman observasi aktivitas siswa dan guru. Hasil catatan lapangan adalah sebagai berikut:

1) Dalam melaksanakan kegiatan pada tahap awal, guru melaksanakan dengan baik, tapi cara guru menyampaikan tujuan pembelajaran kurang memotivasi siswa.

2) Siswa dalam berkelompok bekerja sendiri-sendiri, tidak terjadi masyarakat belajar.

3) Siswa kelihatan ribut dalam kelas.

4) Siswa bekerja seolah-olah hanya mengejar waktu saja.

5) Saat presentasi belum kelihatan adanya tanggapan siswa dari kelompok lain, siswa hanya menulis ke papan tulis kemudian duduk kembali. Jadi, tidak kelihatan adanya diskusi kelas.

6) Siswa sudah mulai mengerti langkah-langkah penyelesaian soal cerita karena ada bantuan LKS, namun pada langkah membuat penyelesaian siswa masih kesulitan menyelesaikannya.

7) Pembagian kelompok memakan waktu yang lama dan saat pembagian kelompok siswa ribut sehingga guru tidak sempat menyimpulkan pembelajaran.

Dalam menggunakan pendekatan CTL sudah ada tiga karakteristik yang deskriptor mendapat kualifikasi sangat baik. Yaitu dalam langkah konstruktivisme, pembagian kelompok, dan membagikan LKS kepada siswa. Sedangkan langkah yang lainnya perlu ditingkatkan lagi di siklus berikutnya.

Jumlah skor yang peneliti peroleh dalam melaksanakan pembelajaran dengan menggunakan pendekatan CTL adalah 28 dan skor maksimal 36. Dengan demikian persentase rata-ratanya adalah 77,8\%. Hal ini menunjukkan bahwa taraf keberhasilan guru dalam menggunakan pendekatan CTL berada dalam kategori cukup.

Dalam kegiatan pembelajaran pertemuan II, siswa terlihat serius dan bersemangat mengikuti proses pembelajaran. Kondisi tersebut juga didukung oleh hasil pengamatan aktivitas siswa yang dilakukan pengamat dengan berpedoman kepada lembaran observasi siswa. Dari hasil pengamatan tersebut, masih ada langkah-langkah yang tidak terlaksana dengan baik sehingga pembelajaran pada pertemuan II belum sempurna.

Hasil observasi yang dilakukan pengamat terhadap aktivitas siswa dalam kegiatan pembelajaran yaitu dengan memberikan tanda cek. Kriteria keberhasilan aktivitas siswa juga mengaju pada kriteria keberhasilan aktivitas guru.

Jumlah skor yang diperoleh siswa dalam melaksanakan pembelajaran dengan menggunakan pendekatan CTL adalah 26 dan skor maksimal 36. Dengan demikian persentase rata-ratanya adalah $72,2 \%$. Hal ini menunjukkan bahwa taraf keberhasilan siswa dalam menggunakan pendekatan CTL berada pada kategori cukup.

Dalam hasil pembelajaran soal cerita tentang keliling persegi dan persegi panjang dilihat dari segi hasil belajar yang dicapai pada siklus I mempunyai rata-rata 6,8. Berdasarkan taraf rata-rata keberhasilan kemampuan 6,8 berada pada taraf cukup.

Hasil pembelajaran menyelesaikan soal cerita tentang keliling persegi dan persegi panjang adalah sebagai berikut: angka perolehan tertinggi adalah 10 dengan banyak siswa 4 orang, nilai 9 dengan banyak siswa 2 orang, nilai 8.4 dengan banyak siswa 3 orang, nilai 7,6 dengan banyak siswa 4 orang, nilai 7.1 dengan banyak siswa 2 orang, nilai 7 dengan banyak siswa 2 orang, nilai 6,1 dengan banyak sisw 1 orang, nilai 5,3 
dengan banyak siswa 1 orang, nilai 4 dengan banyak siswa 1 orang, dan nilai terendah adalah 3 dengan banyak siswa 5 orang.

Selain hasil pengamatan menggunakan lembaran observasi yang dilakukan pengamat, ada juga catatan lapangan yang merupakan catatan penting peneliti dalam suatu rangkaian kegiatan pembelajaran yang perlu diperhatikan dari aktiviatas guru dan siswa. Hasil catatan lapangan dapat disimpulkan sebagai berikut:

1) Siswa sudah mulai bisa berdiskusi dalam kelompok, namun keaktifan siswa masih kurang.

2) Saat presentasi, siswa masih malu-malu untuk menanggapi hasil pekerjaan temannya.

3) Sebagian besar siswa sudah mengerti dengan langkah-langkah pemecahan masalah.

4) Dalam pembagian kelompok siswa sudah mulai agak tenang, karena siswa duduk berdasarkan kelompok pada pertemuan I dan tidak memakan waktu yang lama.

Berdasarkan hasil pengamatan pembelajaran siklus I dan hasil catatan lapangan, maka selama pelaksanaan tindakan pertemuan I dan II diperoleh hasil sebagai berikut:

1) Pembelajaran yang dilaksanakan telah mencerminkan pembelajaran melalui pendekatan CTL, karena secara umum proses pembelajaran berjalan sesuai dengan rencana yang telah disusun.

2) Siswa masih banyak mengalami kesulitan dalam membuat penyelesaian soal cerita.

3) Guru dan siswa belum maksimal melaksanakan komponen CTL dalam pembelajaran.

4) Hasil belajar siswa yang dicapai masih rendah. Hal ini telihat dari tes akhir tindakan. Siswa baru mencapai rata-rata 6,8. Nilai ini berada pada taraf cukup.

5) Aktivitas siswa dalam kelompok masih rendah.

6) Pada saat siswa menyajikan ke depan kelas, siswa tersebut hanya menyajikan lalu duduk kembali, tanpa adanya tanggapan dari siswa lain dan tanpa adanya diskusi kelas.

\section{Siklus II}

Berdasarkan hasil observasi yang dilakukan pengamat terhadap aktivitas peneliti dalam kegiatan pembelajaran pertemuan I siklus II, jumlah skor yang diperoleh adalah 15 dan skor maksimal adalah 17. Dengan demikian persentase skor rata-rata adalah 88,2\%. Hal ini menunjukkan bahwa taraf keberhasilan aktivitas guru selama kegiatan pembelajaran berdasarkan hasil pengamatan pengamat I dalam katergori baik.

Berdasarkan hasil belajar tindakan setelah pembelajaran pada pertemuan I dan II siklus II, hasil catatan lapangan, maka selama pelaksanaan tindakan pertemuan I dan II siklus II diperoleh hasil sebagai berikut:

1) Pembelajaran sudah kelihatan komponen CTL ditiap-tiap langkahnya.

2) Interaksi kelas sudah bagus, yaitu banyak siswa yang mau maju ke depan untuk menuliskan atau menyampaikan hasil pekerjaannya. Siswa kelihatannya mau bertanya, siswa mau mengeluarkan pendapat. Suasana kelas nampak hidup, dan diskusi kelompok dan diskusi kelas berjalan lancar.

3) Skor akhir tindakan menunjukkan peningkatan yang cukup tinggi. Siswa telah mencapai tingkat ketuntasan yang ditetapkan.

Dari refleksi tersebut di atas, maka disimpulkan pembelajaran pertemuan I siklus II telah berjalan dengan yang diharapkan. Berdasarkan hasil belajar siswa dan hasil observasi, hasil belajar siswa telah mencapai rata-rata 8, 46 dan secara klasikal siswa telah mencapai ketuntasan 92\%. Selain itu keaktifan siswa pada siklus II telah meningkat.maka penelitian ini sudah dapat dikatakan berhasil.

\section{Pembahasan}

Berdasarkan hasil catatan di lapangan dan diskusi antara peneliti dengan guru kelas IIIc dan teman sejawat, penyebab dari adanya siswa yang belum dapat menyelesaikan soal cerita yang berkaitan dengan persegi dan persegi panjang adalah karena rendahnya pemahaman siswa terhadap soal yang diberikan dan siswa masih kesulitan dalam menemukan kalimat matematika dari soal cerita. Selain itu, siswa terbiasa belajar sendiri-sendiri (tidak berkelompok) sehingga masyarakat belajar belum tercipta. Hal ini mengakibatkan siswa yang berkemampuan rendah mengalami kesulitan dalam menyelesaikan soal cerita terutama membuat kalimat matematika. Berikut ini akan dibahas lebih lanjut tentang hasil yang ditemukan di lapangan tentang pembelajaran soal cerita melalui pendekatan CTL.

RPP dirancang berdasarkan langkah-langkah pembelajaran menyelesaikan soal cerita melalui pendekatan CTL. RPP yang disusun berdasarkan program semester sesuai dengan waktu penelitian. Dengan Kompetensi Dasarnya memyelesaikan masalah yang berkaitan dengan keliling persegi dan persegi panjang. Indikatornya adalah menyelesaikan soal cerita persegi dan persegi panjang. RPP dilakukan melalui tiga tahap yaitu kegiatan awal, kegiatan inti, dan kegiatan akhir. Tahap inti dibagi menjadi tujuh langkah pendekatan CTL menurut Nurhadi (2003:32) yaitu 1) konstruktivis (contructivism); 2) menemukan (inquiry); 3) bertanya 
(questioning); 4) masyarakat belajar (learning community); 5) pemodelan (modeling); 6) refleksi (reflection); dan 7) penilaian yang sebenarnya (auhtentic assesmen).

Berdasarkan hasil yang dicapai dapat dinyatakan bahwa siswa telah belajar melalui pendekatan CTL sesuai dengan yang diterapkan. Ini dapat dilihat bahwa bahwa hasil belajar sudah sesuai dengan apa yang diharapkan. Karena dalam belajar melalui pendekatan CTL siswa belajar sendiri dalam kelompok yang memiliki kemampuan berbeda. Pada siklus II siswa sudah nampak aktif dan bersemangat dalam belajar. Siswa sudah memahami cara belajar menyelesaikan soal cerita melalui pendekatan CTL.

\section{KESIMPULAN DAN SARAN}

\section{Kesimpulan}

a. Rencana pelaksanaan pembelajaran soal cerita melalui pendekatan CTL menggunakan tiga tahapan pembelajaran, yaitu tahap awal, tahap inti dan tahap akhir. Pada tahap awal kegiatannya yaitu memberikan motivasi, menyampaikan tujuan pembelajaran, dan appersepsi. Pada tahap inti dilaksanakan kegiatan pembelajaran dengan langkah pendekatan CTL, serta pada tahap akhir kegiatan siswa yaitu menyimpulkan pembelajaran dan pemberian PR.

b. Pelaksanaan pembelajaran soal cerita melalui Pendekatan CTL terdiri dari 7 langkah pendekatan CTL dan dikombinasikan dengan langkah-langkah memyelesaikan soal cerita. Pembelajaran menggunakan pendekatan CTL dibagi atas tiga tahapan yaitu tahap awal, tahap inti, dan tahap akhir. Pada tahap awal dilaksanakan kegiatan pengaktifan pengetahuan awal siswa, menyampaikan tujuan pembelajaran, dan appersepsi. Pada tahap inti dilaksanakan langkah-langkah CTL yaitu konstruktivisme, inkuiri, bertanya, masyarakat belajar, pemodelan, refleksi, dan penilaian yang sebenarnya. Pada tahap akhir kegiatan siswa diarahkan untuk menyimpulkan penbelajaran dan memberikan tes akhir.

c. Dilihat dari hasil tes awal yang diberikan guru, siswa hanya memperoleh nilai rata-rata 5,6. Kemudian setelah diadakan tes akhir siklus 1 , siswa memperolrh nilai rata-rata menjadi 6,8. Dan tes akhir siklus II rata-rata siswa meningkat menjadi 8,46. Jadi dilihat dari rata-rata yang diperoleh siswa dengan menggunakan pendekatan CTL hasil pembelajaran siswa dapat ditingkatkan.

\section{Saran}

Berdasarkan simpulan yang telah diperoleh dalam penelitian ini, diajukan beberapa saran untuk dipertimbangkan:

a. Bentuk pembelajaran soal cerita melalui pendekatan CTL layak dipertimbangkan oleh guru untuk menjadi pembelajaran alternatif yang dapat digunakan sebagai referensi dalam memilih pendekatan pembelajaran.

b. Bagi guru yang ingin menerapkan pemebelajaran soal cerita melalui pendekatan CTL, disarankan memperhatikan hal-hal sebagai berikut:

1) Dalam memberikan materi hendaknya disesuaikan dengan konteks sehari-hari

2) Perlu lebih kreatif dalam merancang pembelajaran yang sesuai dengan situasi dunia nyata.

3) Perlu memberikan perhatian, bimbingan dan motivasi belajar secara sunguh-sungguh kepada siswa yang berkemampuan kurang dan pasif dalam kelompok, karena siswa yang demikian sering menggantungkan diri pada temannya.

c. peneliti yang ingin menerapkan bentuk pembelajaran ini, dapat melakukan penelitian serupa dengan materi yang lain.

d. Kepada kepala Sekolah Dasar dan pejabat terkait kiranya dapat memberikan perhatian kepada guru terutama dalam meningkatkan hasil belajar dalam proses pembelajaran.

\section{DAFTAR PUSTAKA}

Depdiknas. 2006. Kurikulum Tingkat Satuan Pendidikan (KTSP). Jakarta: Depdiknas

Hamalik, Oemar. Proses Belajar Mengajar. Jakarta: Bumi Aksara

Mahyuddin, Ritawati dan Yetti Ariani. 2008. Hand Out Mata Kuliah Metodologi Penelitian Tindakan Kelas. Padang: UNP

Mulyasa. 2008. Menjadi Guru Profesional Menciptakan Pembelajaran Aktif dan Kreatif. Bandung: PT Remaja Rosdakarya

Muslich, Masnur. 2007. KTSP (Kurikulum Tingkat Satuan Pendidikan) Dasar Pemahaman dan Pengembangan. Jakarta: Bumi Aksara

Nasar. 2006. Merancang Pembelajaran Aktif dan Kontekstual. Jakarta: PT Gramedia Widiasarana Indinesia

Nurhadi. 2003. Pembelajaran Kontekstual (Contextual Teaching and Learning) dan Penerapannya dalam $K B K$. Malang: UNM 
Prihandoko, Antonius Cahyo. 2005. Pemahaman dan Penyajian Konsep Matematika Secara Benar dan Menarik. Jakarta: Depdiknas

Rahmana, Dian. 2009. Penggunaan Pendekatan Kontekstual dalam Pembelajaran di SD. Padang: UNP (TA tidak dipublikasikan)

Sadijah, Cholis.1999. Pendidikan Matematika II. Jakarta: Depdikbud

Sanjaya, Wina.2008. Srategi Pembelajaran Berorientasi Standar Proses Pendidikan.Jakarta: Kencana Prenada

Solihatin, Etin. Cooperative Leaning Analisis Model Pembelajaran IPS. Jakarta: Bumi Aksara

Subagyo, Joko. 2006. Metode Penelitian dalam Teori dan Praktek. Jakarta: Pt Rineka Cipta

Subana dan Sunarti. Startegi Belajar Mengajar Bahasa Indonesia. Bandung: Pustaka Setia

Subarinah, Sri. 2006. Inovasi Pembelajaran Matematika di SD. Jakarta: Depdiknas

Suharsimi,dkk. 2007. Penelitian Tindakan Kelas. Jakarta: Bumi Aksara

Sulhan, Najib. 2006. Pembangunan Karakter pada Anak Manajemen Pembelajaran Guru Menuju Sekolah Efektif. Surabaya: Surabaya Intelektual Club

Sumiati dan Asra. 2007. Metode Pembelajaran. Bandung: CV Wacana Media

Suyati, Khafid. 2006. Matematika Penekanan pada Berhitung. Jakarta: Erlangga 